\title{
The Political Implications of the South China Sea Ruling on Sino-Philippine Relations and Regional Stability
}

\author{
Hsiao-Chi Hsu ${ }^{1}$
}

On 12 July 2016, the Arbitral Tribunal at the Permanent Court of Arbitration (PCA) in The Hague released its ruling on the South China Sea (SCS) arbitration case brought by the Philippines against China, indicating that the latter's expansive maritime claims in this area have no "legal basis." This decision triggered complex responses from a variety of countries. China immediately issued its rejection of the ruling, calling it "null and void."2 The United States (U.s.), a major ally of the Philippines, called on both parties to abide by the ruling, arguing that the panel's decision is "legal and binding."3 However, while it was successful in this legal battle, the Philippines issued a complicated response. Immediately following the PCA's press release, Philippine Secretary of Foreign Affairs Perfecto Yasay Jr. responded by expressing Manila's welcome of the ruling. He also noted the Philippines' strong "respect for this milestone decision as an important contribution to ongoing efforts in addressing disputes in the South China Sea." Unlike the U.s., Yasay did not urge China to comply with the ruling. Rather, he called on "all those concerned to exercise restraint and sobriety." ${ }^{4}$ The Philippine Presidential Communications Office then announced the government's plan to study the decision and release "a complete and thorough interpretation" of it in five days, while Presidential Spokesperson

1 Assistant Professor, Graduate Institute of Political Science, National Taiwan Normal University, Taipei.

2 Associated Press, China rejects ruling on South China Sea as "null and void", INQUirer.NET (Manila, 13 July 2016), available at http://globalnation.inquirer.net/141037/china-rejects -ruling-south-china-sea-null-void.

3 Agence France-Presse, us: South China Sea ruling "legal and binding", InQuirer. NET (Manila, 13 July 2016), available at http://globalnation.inquirer.net/141051/us-south -china-sea-ruling-legally-binding.

4 Full Text: DFA Secretary Yasay Statement on West PH Sea Ruling, InQuirer.net (Manila, 12 July 2016), available at http://globalnation.inquirer.net/140968/full-text-dfa-foreign-affairs -perfecto-yasay-west-philippine-sea. Emphasis added by the author.

(C) HSIAO-CHI HSU, 2018 | DOI 10.1163/9789004344556_003

This is an open access article distributed under the terms of the CC-BY-NC License 
Ernesto Abella reiterated Manila's promise to "exercise restraint and sobriety." The government's prudent response was in stark contrast to the Filipino public's excitement over the arbitration result, but consistent with the newly inaugurated President Rodrigo Duterte's desire to seek improvements in his country's relations with China. In fact, just days before the decision, Duterte had stated that he did not want to "taunt" Beijing or "flaunt" the scs ruling. ${ }^{6}$ However, the Philippines' arbitration victory has resulted in an increasing uncertainty over the future of Sino-Philippine relations and regional stability. On the one hand, the ruling infuriated the Chinese government and instigated nationalist sentiment in both countries, making foreign policy concession on the SCS issues more difficult and costly. On the other hand, the ruling might further increase SCS stakeholders' desire to participate actively in maritime competition. These factors make the situation in the sCs more complicated and difficult to predict. To explore the impact of the arbitration, this paper offers a preliminary analysis of its political implications on Philippine foreign policy orientation and on regional stability in the scs area.

\section{The Background of the South China Sea Arbitration}

The reason prompting the Philippines to file the scs arbitration was the ongoing dispute over the Spratly/Nansha Islands. There are indications of potentially rich reserves of natural resources such as oil and natural gas in the scs. As such, territorial disputes-especially those between China and Vietnam and China and the Philippines-have become increasingly contentious over the past decade. Being a country highly dependent on energy imports, the Philippines has been eager to secure the sources and reduce the costs of its energy supply by controlling more oil and gas resources in the scs. This was especially apparent after the country's economic losses due to the 2008 global financial crisis and since the rapid oil price surge in 2010. The conflict of interests between Manila's desire for natural resources in the scs and China's maritime expansion, thus, further exacerbated their bilateral frictions. Besides economic and energy considerations, former President Benigno Aquino III (2010-2016)

5 Nestor Corrales, PH gov't to release interpretation of UN ruling in 5 days, INQUIRER.NET (Manila, 13 July 2016), available at http://globalnation.inquirer.net/141065/ph-govt-to-release -interpretation-of-un-ruling-in-5-days.

6 Raul Dancel, Filipinos Cheer Hague Ruling On South China Sea With Funny Memes, The Strait Times (Singapore, 13 July 2016), available at http://www.straitstimes.com/asia/ se-asia/filipinos-cheer-hague-ruling-on-south-china-sea-with-funny-memes. 
considered the modernization of the Philippine air force and navy a policy priority to better protect national interests. To achieve this goal, Aquino saw a closer relationship with the U.S. necessary for enhancing military support from Washington. ${ }^{7}$ The U.s. policy of seeking "strategic rebalance" in Asia since 2010 further complicated the regional situation by encouraging the Philippine president to take a tougher stance toward China. As a result, Sino-Philippine relations have significantly deteriorated and territorial conflicts between the two sides have escalated in recent years.

The conflict between China and the Philippines reached a dangerous point when the two countries engaged in a series of military confrontations over the Scarborough Shoal/Huangyan Island in 2012. On 8 April 2012, a Philippine surveillance plane detected eight Chinese fishing vessels entering the disputed waters. The Philippine naval vessel BRP Gregorio del Pilar attempted to arrest the Chinese fishing crews two days later, but was blocked by two Chinese maritime surveillance ships. ${ }^{8}$ The tensions quickly escalated, as both sides continued to send more ships into the disputed area in order to protect their territorial claims. The military standoff finally came to an end in June 2012, when the Philippines withdrew its military forces from the area. China, however, has retained its presence on and control over the island. The Aquino administration strongly criticized this result, but finally admitted that a return to the shoal was impossible by the end of the year. It then turned to the International Tribunal for the Law of the Sea (ITLOS) under the United Nations Convention of the Law of the Sea (UNCLOS), Annex VII, to address the scs disputes.

The Philippines initiated the arbitration by sending the "Notification and Statement of Claim on West Philippine Sea" to the Chinese government in January 2013. China responded with a "note verbale", which rejected the Philippine claims and returned its notification. China insisted on settling their scs disputes through bilateral negotiation, but the Philippines continued its legal pursuit. A five-member Arbitral Tribunal was later formed to hear the case with the PCA acting as the registry in the proceedings. ${ }^{9}$ In response, China reiterated its rejection to accept the arbitration and to participate in the proceedings. As the deadline to submit its counter-memorial to the Philippines'

7 Kaicheng Lin, Changes in the Philippines' South China Sea Policy, 3 Forum of World Economics \& Politics 6o, 62 (2015) (in Chinese).

8 Ely Ratner, Learning the Lessons of Scarborough Shoal Reef, The National InTEREST (21 November 2013), available at http://nationalinterest.org/commentary/learning-the-lessons -scarborough-reef-9442.

9 Permanent Court of Arbitration, Arbitration between the Republic of the Philippines and the People's Republic of China: Arbitral Tribunal Establishes Rules of Procedure and Initial Timetable, 27 August 2013, available at http://www.pcacases.com/web/sendAttach/227. 
approached, China issued a "Position Paper of the Government of the People's Republic of China on the Matter of Jurisdiction in the South China Sea Arbitration Initiated by the Republic of the Philippines". The document argues that the PCA lacks jurisdiction in the scs case since " $t \mathrm{t}]$ he essence of the subjectmatter of the arbitration is the territorial sovereignty over several maritime features in the South China Sea, which is beyond the scope of the Convention and does not concern the interpretation or application of the Convention."10 However, on 29 October 2015, the Tribunal released its "Award on Jurisdiction and Admissibility" regarding the scs case. The panel decided that "it does have jurisdiction with respect to the matters raised in seven of the Philippines' Submissions" and thus would "convene a further hearing on the Philippines' claims." The other eight submissions in the claims would also be considered further in the following proceedings. ${ }^{11}$ The final decision of the arbitration came out on 12 July 2016, which was in favor of almost all the claims made by the Philippines. It not only rejected China's nine-dashed line claim and historical rights in the scs, but also supported the Philippines' claim that none of the features in the scs qualifies as an island entitled to an exclusive economic zone (EEZ) of 200 nautical miles. Its conclusion that the Taiwan-governed Taiping Island (Itu Aba) does not fulfill the requirements of an "island" according to Article 121(3) of UNCLOS was especially controversial and thus was met with strong criticisms from both Taipei and Beijing. Due to the high level of sensitivity of the scs disputes, the ruling immediately attracted heated discussions about its legitimacy and legality, as well as its political and security implications in the scs region.

\section{Political Implications of the South China Sea Arbitration on Philippine Foreign Policy}

When considering the domestic political implications on the Philippines of the scs ruling, several factors should be taken into consideration: the current administration's foreign policy position, rising nationalist sentiment in the

10 Ministry of Foreign Affairs of the People's Republic of China, Position Paper of the Government of the People's Republic of China on the Matter of Jurisdiction in the South China Sea Arbitration Initiated by the Republic of the Philippines, 7 December 2014, available at http:// www.fmprc.gov.cn/mfa_eng/zxxx_662805/t1217147.shtml.

11 Permanent Court of Arbitration, The South China Sea Arbitration (The Republic of the Philippines $v$. The Republic of China), 29 October 2015, available at http://www.pcacases .com/web/sendAttach/1503. 
country, China's response to the ruling, and the U.s. policy position in the East and South China Seas. These factors will influence the direction of Manila's China and U.s. policies in general, and its scs policy in particular.

\section{$1 \quad$ Duterte's Foreign Policy Position}

The current administration's foreign policy orientation plays the most important role in shaping the country's scs policies. Unlike Aquino's pro-U.s. orientation, Duterte sees a friendly relationship with China as a priority for his country's foreign policy. In early 2016 during the presidential campaign, when most candidates were reluctant to provide details of their China policy positions in front of rising anti-China sentiment among the public, Duterte was one of just two candidates who publicly expressed a willingness to "explor[e] joint development agreements with China."12 After winning the election, Duterte has continued to emphasize the importance of economic cooperation with China and has on several occasions expressed his intention to "reevaluate his country's close ties with Washington."13 Against this backdrop, the Philippine victory in the SCs ruling seemed to create a diplomatic inconvenience as opposed to being an asset for the new president. This can be clearly demonstrated by the administration's cautious response to the scs ruling right after its announcement-so noticeable that it immediately drew close attention on domestic social media. For instance, Foreign Affairs Secretary Yasay's lukewarm responses to the ruling during his press conference were strongly criticized and mocked. A picture of his "gloomy face", posing a striking contrast to his country's legal victory, became broadly circulated and discussed on the internet. ${ }^{14}$ The foreign secretary's somber reaction reflects the Duterte administration's dilemma regarding the scs ruling. On the one hand, Duterte wants to maximize his country's economic and trade benefits by reestablishing good relations with China as soon as possible. To pursue this goal, he has tried to de-escalate the scs disputes since taking office. On the other hand, however, the Philippines' sweeping victory in the scs arbitration will most likely

12 Richard Javad Heydarian, Tale of Two Nations: How Philippines Election Will Impact Manila's China Policy, Asia Times (Hong Kong, 11 April 2016), available at http://www.atimes.com/article/tale-of-two-nations-how-philippines-election-will -impact-manilas-china-policy/.

13 Eric Baculinao, Philippines President Rodrigo Duterte, Asia's 'Trump,' Eyes Closer China Ties, NBC News (New York, 30 June 2016), available at http://www.nbcnews.com/news/ world/philippines-president-rodrigo-duterte-asia-s-trump-eyes-closer-china-n6oo886.

14 Janvic Mateo, Netizens ask: Why So Sad, Yasay?, The Philippine Star (Manila, 14 July 2016), available at http://www.philstar.com/headlines/2016/07/14/1602694/netizensask-why-so-sad-yasay. 
create greater political hurdles for Duterte to make significant concessions over the disputes considering the public's strong support of the ruling and the possibility that his political enemies might use the issue to attack him. Therefore, how to break the country's diplomatic stalemate with China without giving up its victory in the SCS arbitration poses a difficult challenge to the new administration.

Duterte's strategy to cope with this dilemma was to seek direct talks with China first. His decision to designate former president Fidel V. Ramos as special envoy to China paid off. Ramos' meetings with "old friends" in Hong Kong successfully broke the bilateral stalemate and eventually led to Duterte's official visit to Beijing. ${ }^{15}$ This was an important foreign policy success for the president, for he was able to obtain significant economic benefits from China during his trip. To demonstrate its welcome of the president, China lifted its restrictions on the importation of Philippine fruits that had been in place since the 2012 conflict over the Scarborough Shoal/Huangyan Island. It also expressed interest in increasing its imports of Philippine agricultural and aquaculture products. ${ }^{16}$ After the restoration of bilateral relations, the Duterte administration became more open to expressing its willingness to set aside the scs for the sake of good relations with China. ${ }^{17}$ While this policy attitude has resulted in a gradual increase of domestic criticism, there is no sign that the current government might consider a different path at this point.

\section{2}

\section{Rising Domestic Nationalism}

A second factor that might shape the scs ruling's political impact is the growing anti-China sentiment among Filipinos. According to a survey conducted by the Social Weather Stations, Filipinos have expressed a decline in trust of China during the past five years: the net trust (\% of much trust minus $\%$ of little trust)

15 Cris Larano, Philippines' Duterte Asks Ex-President to Begin Talks in South China Sea Dispute, The Wall Street Journal (New York, 15 July 2016), available at http://www .wsj.com/articles/philippines-duterte-wants-ex-president-ramos-to-meet-with-china -on-maritime-dispute-1468520651; Associated Press, 'Ramos arrives in Hong Kong, talks China ties', the Philippine Star (Manila, 9 August 2016), available at http://www.philstar .com/headlines/2016/08/og/1611719/ramos-arrives-hong-kong-talks-china-ties.

16 Louise Maureen Simeon, China Lifts Import Ban on Philippine Bananas, The Philip pine STAR (Manila, 7 October 2016), available at http://www.philstar.com/business/2016/10/o7/ 1630958/china-lifts-import-ban-philippine-bananas.

17 Jim Gomez, Duterte Says He'll Set Aside Sea Feud Ruling against China, The PhilipPINE STAR (Manila, 17 December 2016), available at http://www.philstar.com:8080/ headlines/2016/12/17/1654340/duterte-says-hell-set-aside-sea-feud-ruling-against-china. 
dropped from +17 in June 2010 to -45 in June $2015 .{ }^{18}$ Along with ongoing territorial disputes, such anti-China sentiment made foreign policy one of the important issues during the 2016 presidential campaign. The Philippines' victory in the sCs arbitration might once again stir anti-China sentiment. For instance, according to news reports, the word "Chexit", an abbreviation of "China exit" which was similar to "Brexit" for the British exit from the E.U., quickly became a popular topic on Twitter in the Philippines. ${ }^{19}$ This development suggests that anti-China sentiment might become a factor that the Duterte administration has to take into consideration when handling the SCs disputes in particular, and its relations with China in general.

Domestic support for the scs ruling might play a role in explaining the fluctuations in the Duterte administration's early responses to it. Two days after the release of the ruling, the Philippine Department of Foreign Affairs issued a statement on the eve of the biennial Asia-Europe Meeting (ASEM) Summit on 15-16 July, indicating that Yasay would discuss "the Philippines' peaceful and rules-based approach on the South China Sea and the need for parties to respect the recent decision of the Arbitral Tribunal" in the summit. ${ }^{20}$ Although Yasay still did not urge China to respect the ruling, the fact that he raised the scs issues in his speech displayed a firmer stance by the Philippines compared to its initial somber reaction on 12 July. Then, however, on 22 July in a speech in Buluan, Maguindanao, Duterte hinted that the Philippines could set aside the scs ruling as Ramos suggested in exchange for the resumption of bilateral talks with China. He emphasized that the restoration of bilateral relations would benefit the southern island economically. "It's China that has money, not America. America doesn't have money", the president said. ${ }^{21}$ Later on, Yasay again brought up the scs disputes in the 2016 ASEAN Ministers' Meeting

18 Social Weather Stations, Second Quarter 2015 Social Weather Survey, available at https:// www.sws.org.ph/pr2015070gb.htm.

19 Voltaire Tupaz, \#CHexit: Filipinos Celebrate PH Victory over China, THE RApPle R (Manila, 12 July 2016), available at http://www.rappler.com/move-ph/139492-chexit-filipinoscelebrate-ph-victory-china.

20 Agence France-Presse, Philippines Urges Beijing to 'respect' Sea Ruling, The StAR (Manila, 14 July 2016), available at http://www.thestar.com.my/news/regional/2016/07/14/philippinesurges-beijing-to-respect-sea-ruling/; Agence France-Presse, 'Beijing Faces S. China Sea Rebuke At Europe-Asia Summit', ABC News (New York, 15 July 2016), available at http:// news.abs-cbn.com/overseas/o7/14/16/beijing-faces-s-china-sea-rebuke-at-europe-asia -summit.

21 Paterno Esmaquel II, Duterte Hints He Can Set Aside Hague Ruling For China Talks, ThE RAPPLER (Manila, 23 July 2016), available at http://www.rappler.com/nation/14066o -duterte-ramos-hague-ruling-talks-china. 
(AMM) on July 25, saying that he hoped a joint communique after the meeting would address the issue. He stressed that the ruling is "final and binding to all parties concerned, a clearly established fact...[with] significant implications for the entire region, not just the coastal States bordering the South China Sea." ${ }^{22}$ Duterte also once told the press that " $[\mathrm{w}]$ hen the time comes for negotiations, we will not go out of the arbitral award". ${ }^{23}$ The above incidents show a high degree of inconsistency in the Duterte administration's attitudes toward the scs ruling, which seem to reflect the government's difficulty in reconciling its China policy position with its scs arbitration victory. However, as the two countries began to restore their diplomatic relationship, the Duterte administration became more clear and consistent in its SCS position-to downplay the disputes for the sake of better bilateral relations unless further conflict emerges. This policy principle can be further demonstrated by the Philippine's low-profile response to a U.s. report finding China's installation of "antiaircraft and anti-missile weapons" on its artificial islands in the South China Sea in early January 2017. ${ }^{24}$

Domestic public opinion continues to disagree with Duterte's current approach of handling the scs disputes. According to a survey conducted by the Pulse Asia Research Institute from 6 to 11 December, 84 percent of the Filipinos agree (with 44 percent saying 'very much agree' and 40 percent 'agree') with the statement that "the government should assert its right on the West Philippine Sea as stipulated in the decision of Permanent Court of Arbitration."25 Although the government has been aware of the public's sentiment toward the scs disputes, it nonetheless has not been affected by it. Two reasons might have contributed to this. First, foreign policy has not been considered a prioritized national issue by most Filipinos, as Philippine law scholar Jay

22 Recto Mercene, Yasay Hammers on PCA Decision on South China Sea in Rallying ASEAN vs China, Business Mirror (Manila, 25 July 2016), available at http://www.businessmirror.com.ph/2016/07/25/yasay-hammers-on-pca-decision-on-south-china-sea -in-rallying-asean-vs-china.

23 Alexis Romero, Pia Lee-Brago, and Marvin Sy, FVR's China Mission: No Hard Proposals, Just Dialogue, The Philip ine Star (Manila, 4 August 2016), available at http://www.philstar .com/headlines/2016/o8/04/1609949/fvrs-china-mission-no-hard-proposals-just -dialogue.

24 Associated Press, Philippines protests China's weapons installation on islands, THE PhilipPine InQuirer (Manila, 16 January 2017), available at https://globalnation .inquirer.net/151709/philippines-protests-chinas-weapons-installation-islands.

25 Kristen Angeli Sabillo, 8 in 10 Filipinos Want PH to Assert Rights in South China Sea-Pulse Asia, The PhIlippine InQuirer (Manila, 27 January 2017), available at https://globalna tion.inquirer.net/152106/8-10-filipinos-want-ph-assert-rights-south-china-sea-pulse-asia. 
Batongbacal observes. ${ }^{26}$ Therefore, while the public has strong support for the scs ruling, it is less likely that they will act on it unless the issue becomes critical to their well-being. Second, the public might have concerns about Duterte's handling of the scs disputes, but the president's popularity remains soundover 80 percent during the last quarter of $2016 .{ }^{27}$ Under these circumstances, the Duterte administration remains less influenced by the public's enthusiasm with the scs victory. However, the extent to which this situation will endure will depend on future development of Sino-Philippine relations. If talks with China fail to generate substantial economic and political benefits to its country, the Duterte administration might have to face growing domestic dissatisfaction and be forced to answer to the public's anti-Chinese sentiment. The president's domestic opponents might also try to exploit such nationalism as a political weapon by that time. But currently, public opinion seems to play only a limited role.

\section{3} The China Factor

The third factor that shapes the scs ruling's political impact on the Philippines is China's future approach to the scs disputes. Beijing has responded negatively to the SCs ruling, despite continuing to emphasize a willingness for negotiations and joint development. It released a number of statements and documents to refute the decision and to clarify China's position on the scs. ${ }^{28}$ These materials shed some light on how China would handle the scs disputes after the arbitration. On the one hand, political statements made by Chinese officials display a strong resentment towards the scs ruling. For example, China's Ministry of Foreign Affairs (MFA) issued a statement calling the award "null and void" and as having "no binding force" and further emphasized that "China neither accepts nor recognizes it." ${ }^{29}$ MFA Spokesperson Lu Kang also

26 Kristen Angeli Sabillo, Disconnect? Duterte Admin Foreign Policy vs. Public Sentiment, The Philippine InQuirer (Manila, 27 January 2017), available at https://globalnation .inquirer.net/152137/disconnect-duterte-admin-foreign-policy-vs-public-sentiment.

27 Kristen Angeli Sabillo, Duterte Approval Rating at 83\%-Pulse Asia, The Philippine INQUiRER (Manila, 6 January 2017), available at http://newsinfo.inquirer.net/859906/ duterte-approval-rating-at-83-pulse-asia.

28 Feng Zhang, South China Sea Arbitration Award: Breathtaking (But Counterproductive), The National Interests (16 July 2016), available at http://nationalinterest.org/blog/ the-buzz/south-china-sea-arbitration-award-breathtaking-17004.

29 Ministry of Foreign Affairs of the People's Republic of China, Statement of the Ministry of Foreign Affairs of the People's Republic of China on the Award of 12 July 2016 of the Arbitral Tribunal in the South China Sea Arbitration Established at the Request of the Republic of the Philippines, 12 July 2016, available at http://www.fmprc.gov.cn/mfa_eng/wjdt_665385/2649 _665393/tr1379492.shtml. 
questioned the Arbitral Tribunal's lawfulness and again emphasized China's "steadfast position of not accepting nor participating in the arbitration case and not accepting nor recognizing the so-called award."30 This position was also reiterated by President Xi Jinping and Foreign Minister Wang Yi. Wang made a strong statement criticizing the scs ruling as "completely a political farce staged under legal pretext."31 Vice Foreign Minister Liu Zhenmin further indicated that the precondition to resume bilateral negotiations is for the Philippines to give up the ruling. ${ }^{32}$ On the other hand, however, in the two policy documents, "Statement of the Government of the People's Republic of China on China's Territorial Sovereignty and Maritime Rights and Interests in the South China Sea" and "China Adheres to the Position of Settling Through Negotiation the Relevant Disputes Between China and the Philippines in the South China Sea", the Chinese government did not consider a hawkish approach a priority in handling the scs disputes. ${ }^{33}$ On the contrary, besides emphasizing Beijing's willingness to settle the scs disputes through negotiation and avoid confrontation, these two documents also only briefly mention the term of "nine-dashed line". This might indicate the Chinese government's "intention to

30 Ministry of Foreign Affairs of the People's Republic of China, Foreign Ministry Spokesperson Lu Kang's Remarks on Japanese Foreign Minister's Statement on the Award of South China Sea Arbitration initiated by the Philippines, 12 July 2016, available at http://www .fmprc.gov.cn/mfa_eng/xwfw_665399/s2510_665401/2535_665405/t1380245.shtml.

31 Ministry of Foreign Affairs of the People's Republic of China, Remarks by Chinese Foreign Minister Wang Yi on the Award of the So-called Arbitral Tribunal in the South China Sea Arbitration, 12 July 2016, available at http://www.fmprc.gov.cn/mfa_eng/wjdt_665385/ zyjh_665391/t1380oo3.shtml.

32 In response to a question raised by a CNN reporter regarding whether there would be a precondition for resuming bilateral talks between Beijing and Manila, Liu said that "China expects the new Filipino government to cooperate and recognize that the ruling is nothing more than a piece of waste paper and cannot be enforced. China hopes that the Filipino side will set aside the award and return to the negotiation table". See Paterno Esmaquel II, China Rejects Talks With Ph If "Based On Ruling", The RAPPLen (Manila, 13July 2016), available at http://www.rappler.com/nation/139724-china-philippines-bilateral -talks-hague-ruling?utm_source=twitter\&utm_medium=referral\&utm_medium=share bar.

33 Ministry of Foreign Affairs of the People's Republic of China, Statement of the Government of the People's Republic of China on China's Territorial Sovereignty and Maritime Rights and Interests in the South China Sea, 12 July 2016, http://www.fmprc.gov.cn/ mfa_eng/wjdt_665385/2649_665393/t1379493.shtml; China Adheres to the Position of Settling Through Negotiation the Relevant Disputes Between China and the Philippines in the South China Sea, 13 July 2016, available at http://www.fmprc.gov.cn/mfa_eng/ wjdt_665385/2649_665393/tı380615.shtml. 
seek regional peace and stability". ${ }^{34}$ This suggests that although Beijing strongly rejected the arbitration result, an escalation of bilateral confrontation is not of its best interests.

Nonetheless, China's prudence in handling the scs disputes faces two challenges: one from the external environment and another from its domestic politics. Externally, the scs ruling undermines the moral prestige and legality of China's maritime claims and thus might encourage other claimant States to take similar legal action. Vietnam is one of those countries likely to do so, considering that Sino-Vietnam relations have also experienced serious deterioration since 2011. Anti-China sentiment is much higher in Vietnam than in the Philippines, as demonstrated by the disastrous anti-China protests over China's oil rig in 2014. Against this backdrop, Vietnam has been very supportive of and has closely followed the Philippines' arbitration case against China. Moreover, like the Philippines, Vietnam has cultivated close military ties with the U.S. After the sCS ruling came out, Vietnam was one of the few ASEAN States that immediately welcomed it. Manila's victory opens a window of opportunity for Hanoi to address its maritime disputes with China via international law. Other stakeholders in this region or even in the East China Sea (ECS) might also want to do the same. The fact that Vietnam, Malaysia, Indonesia, Thailand and Japan all sent observers to the arbitration hearings demonstrates these States' strong interest in the case. Thus, there is a distinct likelihood of an increase in the legal battles in this region.

Internally, just like the Philippines, the Chinese government also faces public pressure when addressing the sCs disputes. As a result of rising nationalism over the past decade, the public has become more interested in and sensitive about their country's foreign policy behavior and international situation. Protests against foreign enterprises and threats to boycott or boycotts of foreign products can often be seen when other countries are considered misbehaving diplomatically toward China. ${ }^{35}$ The 2012 Chinese boycott against Japanese products was especially influential, and caused significant damage to the latter's economy. A similar case can also be found in the Sino-Philippine conflict over the Scarborough Shoal/Huangyan Island in the same year. However, while strong nationalist sentiment could sometimes increase the

34 Feng Zhang, South China Sea Arbitration Award: Breathtaking (But Counterproductive), The National Interests (16 July 2016), available at http://nationalinterest.org/blog/ the-buzz/south-china-sea-arbitration-award-breathtaking-17004.

Two earlier examples of this include CNN's negative reports on and French President Jacques R. Chirac's criticism of the Chinese government's handling of the 2008 Tibet riots, as well as Japan's nationalization of the disputed Diaoyu/Senkaku Islands in 2012. 
Chinese government's credibility to signal its resolve to stay firm when handling diplomatic disputes, they also constrain the government's policy choices by increasing the costs of compromises. ${ }^{36}$ Aware of this, Beijing has been cautious in handling domestic frustration over the scs ruling. Hours before the ruling came out, the Beijing municipal government issued an emergency notice stating that the city is in a "state of alert" and asking law enforcement to increase its security forces to prepare for "unexpected events" for a week. ${ }^{37}$ This appears to be an effort to prevent the recurrence of incidents like the 2012 anti-Japanese riots. To avoid an outburst of extreme nationalism, the central government also closely monitored internet discussions and took action to delete internet posts "calling for military action against the U.s. or the Philippines to defend China's territorial claims". ${ }^{38}$ While these measures demonstrate the government's capability in containing public discourses and behavior, they also reveal the growing importance of nationalism in Chinese foreign policy.

Considering the international and domestic pressures discussed above, it would be risky for the Chinese government to make too many compromises over the SCS issues, since a softer position might encourage more legal challenges from other stakeholders in maritime disputes and make the government look weak in front of the its people. As a result, although Beijing and Manila have the incentive to build closer ties, substantial progress on addressing the territorial disputes will remain difficult and the scs ruling will continue to complicate their bilateral relationship.

\section{4}

\section{The U.s. Factor}

The last factor is Washington's attitude toward the scs disputes and Sino-U.s. competition in the area. Although the U.s. strongly supports the SCS ruling, the Duterte administration's eagerness to rebuild diplomatic ties with China makes it more difficult for Washington to seek further Philippine cooperation on this issue in the short run. Future U.s.-Philippine relations might also become more dynamic than they were during the Aquino administration.

36 Jessica C. Weiss, Powerful Patriots: Nationalist Protest in China's Foreign Relations (2014) 4. Also see James Reilly, Strong Society, Smart State: The Rise of Public Opinion in China's Japan Policy (2011).

37 J. Michael Cole, Beijing in "State of Alert" Ahead of Key Ruling on South China Sea, THE News Lens (Taipei, 12 July 2016), available at http://international.thenewslens.com/ article/44063.

38 Bethany Allen-Ebrahimian, After South China Sea Ruling, China Censors Online Calls for War, Foreign Policy (12 July 2016), available at http://foreignpolicy.com/2016/07/12/ after-south-china-sea-ruling-china-censors-online-calls-for-war-unclos-tribunal/ ?wp_login_redirect=0. 
However, despite Duterte's desire for economic benefits from China, maintaining its ties to the U.S. remains necessary for his country's security interests. But currently, Duterte's top priorities are economic development and a war on drugs. Therefore, improvements of Sino-Philippine relations would be more urgent for the president than strengthening military cooperation with the U.S.

On the U.s. side, although Washington continues to insist that it does not take sides on sovereignty disputes in the scs, its strong support of the ruling and emphasis on the freedom of navigation shows a significant increase in its interests in the region. This in evinced by an official document published by the Bureau of Oceans and International Environmental and Scientific Affairs in 2014, which explicitly refutes China's nine-dashed line claim and historic rights in the scs. ${ }^{39}$ While it is not in Washington's interests to encourage confrontation, ensuring the Arbitral Tribunal's ruling is recognized and respected by concerned parties is strategically important for it contain China's maritime expansion. Therefore, during then Secretary of State John Kerry's first visit to the Duterte administration in July 2016, Washington tried to push Manila to base its future negotiations with Beijing on the scs ruling. ${ }^{40}$ Further complicating the U.s. influence on the Philippine's scs policy is the conflict between the Obama and the Duterte administrations regarding the latter's radical antidrugs policy. Duterte made several verbal attacks against Obama publicly and threatened to sever Manila's close ties with Washington. ${ }^{41}$ It is still unclear how the new president, Donald Trump, will handle U.s.-Philippine relations. Unlike Obama, Trump does not see a problem with Duterte's violent anti-drugs campaign. This different attitude seems to create an opportunity for the two old allies to amend their deteriorated relations since Duterte took office. However, as the Trump administration considers scs policy a strategic priority, it will be risky to get too optimistic about the future developments of the relationship between the two sides in the short term. In other words, while bilateral disagreements over moral issues between Washington and Manila are likely to

39 Bureau of Oceans and International Environmental and Scientific Affairs, Limits in the Seas: China's Maritime Claims in the South China Sea (2014), available at http://www.state.gov/documents/organization/234936.pdf.

40 Estrella Torres, Leila B. Salaverria, Duterte: $P H$-China Talks to Be Based on Int'l Law, ThE PhilipPine Daily InQuirer (Manila, 25 July 2016), available at http://globalnation. inquirer.net/142080/duterte-ph-china-talks-to-be- based-on-intl-law.

41 Richard C. Paddock, Rodrigo Duterte, Pushing Split With U.s., Counters Philippines' Deep Ties, The New York Times (Manila, 26 October 2016), available at https://www .nytimes.com/2016/10/27/world/asia/philippines-duterte-united-states-alliance.html? $\mathrm{r}=0$ \&module $=$ ArrowsNav\&contentCollection $=$ Asia\%2oPacific\&action=keypress\&region $=$ FixedLeft\&pgtype=article. 
reduce, escalating Sino-U.s. tensions in the South China Sea might nonetheless further complicate Duterte's foreign policy choices. As a result, the triangular relations among the three actors will become even more dynamic in the future, and the scs arbitration will continue to play a role in it.

The four factors discussed above are crucial for understanding how the SCS ruling will influence the Philippines' handling of its maritime disputes with China and how Sino-Philippine relations might develop in the post-arbitration era. So far, President Duterte's pro-China orientation seems to play the most important role in shaping the Philippines' responses to the arbitration result. China's rejection of the scs ruling and future policy behavior-also constrained by the scs ruling - in the region will also influence the extent to which Duterte is willing to cooperate on the scs issue. Washington's attempt to pressure Duterte into firmly upholding the scs ruling might not be effective unless it can provide higher levels of substantial economic benefits to the Philippines. Domestic political opinion is currently the least influential factor by far. Its impact, however, might be more significant if Duterte's power position becomes unstable in the future. Under such circumstance, the president might be more likely to turn to nationalist sentiment to consolidate his domestic support and defend himself from possible attacks by his political opponents. As a result, a tougher scs policy position and firmer emphasis on the scs ruling might emerge.

Regional Political Impact of the South China Sea Ruling

Other than influencing Sino-Philippine relations, the scs ruling might also have significant regional impact by causing more diplomatic friction in the scs. As mentioned earlier, the ruling might amplify other scs stakeholders' ambition to seek more active participation in the maritime competition. For instance, besides urging China to abide by the scs ruling, Australian Foreign Minister Julie Bishop responded to the scs ruling by emphasizing that her country would continue freedom of navigation exercises in the region. In return, Beijing issued a harsh warning to Canberra, urging it to "carefully talk and cautiously behave." 42 This tough response reflects China's anxiety about rising challenges in the SCS in the post-arbitration period. To deter potential challenges to its national interests in the region, the Chinese government might try

42 Matthew Carney, China Warns Australia: Stay out of the South China Sea or Risk Damage to Bilateral Relations', ABC News (New York, 15 July 2016), available at http://www.abc.net .au/news/2016-07-15/china-tells-australia-stay-out-of-the-south-china-sea/7631492. 
to demonstrate a strong resolve by accelerating its military buildup and increasing its military activities. For instance, days before the ruling came out, China conducted a series of military drills from 5 to 11 July. Later, in response to the scs ruling, it has threatened to impose an scs air defense identification zone (ADIZ). While these military actions signaled Beijing's resolve to defend its national interests, they also increased the sense of insecurity among surrounding States. Indonesia, for instance, has begun to take action in response to rising regional tensions. After the scs ruling was announced, Indonesian Defense Minister Ryamizard Ryacudu said in an interview that Jakarta will "sharply strengthen security around its South China Sea islands where there have been clashes with Chinese vessels." ${ }^{33}$ Ryacudu's remark reflects an assertive change in his country's maritime policy regarding the escalating Sino-Indonesian conflict over fishing rights in the waters near the Natuna Islands. Indonesia's responses to the scs ruling might offer some insights for understanding future Sino-Philippine relations in the long-term. Like the Philippines, Indonesia is eager to obtain more trade opportunities and financial investments from China to improve its infrastructure. Nonetheless, such economic needs do not prevent it from pursuing a tougher position in the scs. ${ }^{44}$ This shows that economic interests do not necessarily supersede security concerns, especially when these two concerns are intertwined.

However, China's biggest challenges come from two non-claimants in the scs - the U.s. and Japan. Despite the U.s. efforts to reduce tensions by urging stakeholders in the region to exercise restraint, ${ }^{45}$ it is pushing for compliance with the scs ruling, emphasis on freedom of navigation, and actions to strengthen security cooperation with its East and Southeast Asian allies

43 Agence France-Presse, Indonesia Details Defense Plan after South China Sea Ruling, THE RAPPLER (Manila, 13 July 2016), available at http://www.rappler.com/world/regions/ asia-pacific/indonesia/bahasa/englishedition/1396o9-indonesia-defense-plan-south -china-sea-ruling.

44 Keith Johnson, Can Indonesia Afford a Fish War With China?, Foreign Policy (8 July 2016), http://foreignpolicy.com/2016/o7/o8/can-indonesia-afford-a-fish-war-with-china/.

45 Lesley Wroughton and John Walcott, U.S. Launches Quiet Diplomacy to Ease South China Sea Tensions, Reuters (London, 14 July 2016), available at http://www.reuters .com/article/us-southchinasea-ruling-usa-idUSKCNoZT2TY. The U.s. has also tried to calm China by avoiding to discuss the ruling directly. Therefore, when National Security Advisor Susan Rice visited China and met with Xi Jinping on July 25, their discussions did not focus on the scs issues. Rather, she emphasized that it is in America's interest to see China succeed and that it is important for both powers to work together to address major global issues. See Gillian Wong, Susan Rice Visits China, U.s. News (Washington, 25 July 2016), available at http://www.usnews.com/news/world/articles/2016-07-25/ obama-aide-visits-china-after-south-china-sea-ruling. 
all continue to raise Beijing's security concerns. The long-term hostility and distrust by the Chinese government and people toward the U.s. only deepened after the scs ruling. Complicating the situation is the announcement of the location of U.s. deployment of the Terminal High Altitude Area Defense (THAAD) system in South Korea, ${ }^{46}$ which further convinces China of America's intentions of containment.

Like the U.s., Japan also welcomed the ruling and called on both sides to abide by it. Being a stakeholder in the disputes over the Diaoyu/Senkaku Islands in the East China Sea, Japan's position on the scs issues is highly sensitive to China. Beijing has considered Tokyo's effort to enhance its security linkages with Manila and Hanoi in recent years a strategic move aimed at containing China's maritime expansion. Therefore, as Japanese Prime Minister Shinzo Abe and Chinese Premier Li Keqiang discussed the scs ruling during the ASEM summit in Mongolia, Li reiterated China's rejection and bluntly told Abe to "exercise caution in its own words and deeds, and stop hyping up and interfering." ${ }^{37}$ Nonetheless, for Japan, it would be impossible to give up the benefits of the ruling. Therefore, to increase its influence in the region, Japan announced a decision to increase its defense attaches in the Philippines and Vietnam to boost its security relations with these two countries. ${ }^{48}$ Japanese Foreign Minister Fumio Kishida also visited President Duterte and Secretary Yasay to build closer ties with the Philippine leadership. ${ }^{49}$

Drawing on the above analysis, it seems reasonable to argue that when faced with more ambitious challengers in both the South and East China Seas, China would have little choice but to pursue a military deterrence strategy. The purposes are two-fold: externally, Beijing needs to demonstrate its capability to protect its national interests in the South and East China Seas to deter

46 Reuters, China Stands Ground on THAAD, Senkakus as It Advances toward Control of West Pacific, The Japan Times (Tokyo, 10 August 2016), available at http://www.japantimes .co.jp/news/2016/o8/10/asia-pacific/china-stands-ground-thaad-senkakus-advances -toward-control-west-pacific/\#.V7COh_l95hE.

47 Sue-Lin Wong and Terrence Edwards, China Tells Japan to Stop Interfering in South China Sea, Reuters (London, 15 July 2016), available at http://www.reuters.com/article/ us-southchinasea-ruling-idUSKCNoZVo6F.

48 Jiji, Japan to increase defense attaches in Philippines, Vietnam, The Japan Times (Tokyo, 11 August 2016), available at http://www.japantimes.co.jp/news/2016/08/11/ national/politics-diplomacy/japan-increase-defense-attaches-philippines-vietnam/\#. $\mathrm{V}_{7}$ COkfl95hE.

49 Minoru Satake, us, Japan Court Duterte over South China Sea Dispute, NiкKEI (Tokyo, 11 August 2016), available at http://asia.nikkei.com/Politics-Economy/International -Relations/US-Japan-court-Duterte-over-South-China-Sea-dispute. 
potential challengers; domestically, the Chinese leadership cannot afford to look weak and incompetent in front of its own people when addressing the scs disputes. Against these backdrops, China's continuation of military buildup and more frequent military operations in the two seas will be inevitable in the post-scs-arbitration era, as demonstrated by the situations following the announcement of the Arbitral Tribunal's decision. On the same day of the ruling, two Chinese civilian aircraft landed at Subi and Mischief Reefs. On August 2, Chinese navy conducted a live-fire military drill in the East China Sea. On August 6, the Chinese air force flew bombers and fighter jets over the Spratly/Nansha Islands for "combat patrol" for a show of strength. ${ }^{50}$ On the same day, Japan issued a protest against China after spotting a fleet of three armed Chinese coastguard vessels and 230 fishing boats sailing close to the disputed Diaoyu/Senkaku Islands. ${ }^{51}$ Satellite photographs also reveal that China seems to be constructing reinforced aircraft hangars on the disputed Fiery Cross, Subi and Mischief Reefs. ${ }^{52}$ These military actions seem to suggest a deterrence intention. However, for its neighbors, these actions could mean increased military threats that need to be met with greater defense capability and maybe stronger U.s. military support. The result will likely be a security dilemma in the region, as all parties' defensive intentions lead to an arms race and increasing prospect of military conflict.

\section{Conclusion}

The scs ruling creates opportunities and challenges for a variety of States, including both claimants and non-claimants in the region. While it is difficult to predict future development, this paper discusses some possible political influences of the ruling on Sino-Philippine relations and regional stability. The ruling's influence on the Philippines' scs policy will be determined by four important factors, although with varying degrees of influence: the Duterte administration's foreign policy orientation, the rising anti-China sentiment

50 Max Lewontin, Why Did China Fly "Combat Patrols" over The Spratly Islands?, ThE Christian Science Monitor (Boston, 6 August 2016), available at http://www .csmonitor.com/World/Asia-Pacific/2016/o8o6/Why-did-China-fly-combat-patrols-over -the-Spratly-Islands.

$5^{1} \quad$ Kiyoshi Takenaka and Osamu Tsukimori, Japan Protests after Chinese Coastguards and Fishing Boats Sail near Disputed Islets, ReUters (London, 1 August 2016), available at http://www.reuters.com/article/us-japan-china-islands-idUSKCN1oG1KP.

$5^{2}$ Csis, Build It and They Will Come: China Preps Spratlys for Military Aircraft, (1 August 2016), available at https://amti.csis.org/build-it-and-they-will-come/. 
among Filipinos, China's responses to the ruling, and Sino-U.s. competition in the scs. Manila's mixed responses to the ruling during the first few days after its announcement suggest that although Duterte prefers better ties with China, the public's anti-China sentiment might have stopped him from making substantial compromises to his Chinese counterpart too fast. Eventually, however, Duterte chose to cope with the ruling's challenge by prioritizing the economic benefit of restoring Sino-Philippine relations over the scs issue. His determination to pursue close ties with China has to a great extent reduced the sCs ruling's direct impact on Philippine foreign policy. But the degree to which the Sino-Philippine reconciliation will go will have to depend on China's future policy moves in the South China Sea. As the scs ruling might increase Beijing's sense of insecurity and its cost to make compromises, the room for mutual cooperation on the Scs disputes between China and the Philippines is rather limited. This limitation would in turn raise the uncertainty of their bilateral relations in the long term. Continuous Sino-U.s. competition is also key to the Philippines' scs policy, as it will define the extent to which the Philippines has to strike a balance between its economic interests and security needs. At the regional level, the scs ruling put China on the defensive and thus might increase the instability in the scs as the regional hegemon now sees a heightened need to demonstrate its military capabilities and resolve. As tensions continue to intensify, risks of armed confrontation will also increase. Therefore, the SCS ruling's political impact might be most significant and dynamic at this level. 